\title{
LECANORA SCHISTINA (NYL.) ARNOLD, A LICHEN WITH DIMORPHIC CONIDIA
}

\author{
J. ETAYO^ and P. DIEDERICH $\ddagger$
}

\begin{abstract}
The lichen Lecanora schistina (Nyl.) Arnold has two kinds of conidia: filiform microconidia and obpyriform macroconidia. Both appear mixed in the same conidioma, the former being much more abundant. Sometimes these conidiomata contain a third type of conidia (microconidia) belonging most probably to a lichenicolous coelomycete living in the conidiomata of the lichen.
\end{abstract}

\section{Introduction}

We recently collected Lecanora schistina ( $=$ L. pomensis Zahlbr., ? $L$. praepostera auct. non Nyl.) on a vertical, shaded and north-oriented wall together with Haematomma ochroleucum, Lecanactis latebrarum, Lecanora orosthea, Ochrolechia tartarea, Roccella fuciformis, $R$. phycopsis, etc. The thallus was parasitized by a species of Rosellinula, similar to $R$. frustulosa (known from Lecanora frustulosa and L. argopholis) and a dematiaceous hyphomycete with large brown cells. These two lichenicolous fungi did not reduce the vitality of the host, which is abundantly fertile with apothecia and conidiomata. The thallus has little crateriform holes containing the conidiomata. Like in other genera (e.g. Micarea, Coppins 1983), the immersed conidiomata are pigmented only in the upper part and the pigments are the same as in the epithecium of the apothecia (greenish brown, $\mathrm{K}+$ intensifying, $\mathrm{N}+$ red-brown).

We were surprised to find two different kinds of conidium in the same conidioma, and sometimes, the conidiomata contained even a third type of conidium. Such dimorphic conidia in the same conidioma are very rare amongst coelomycetes (Sutton 1980) and have recently been reported in a lichenicolous coelomycete [Stromatopogon baldwinii Zahlbr., Diederich (1992)].

Two kinds of conidia are known in various lichens (Coppins 1983), and some Micarea species even have three different types of conidia, micro-, meso- and macroconidia, but always in different conidiomata. Therefore, this is the first example of a lichenized fungus with two types of conidia in the same conidioma.

\section{Material and Methods}

The conidiomata were studied by light microscopy using hand sections. The measurements were made in water and the illustrations from specimens in $\mathrm{KOH}$ and lactophenol cotton blue.

\section{Description}

Conidiomata pycnidial, immersed in holes of the thallus of Lecanora schistina, the holes having a crateriform appearance, ellipsoid to globose, $160-240 \mu \mathrm{m}$

^Navarro Villoslada 16-3 dcha, E-31003 Pamplona, Spain.

\$22, rue de la Solidarité, L-8020 Strassen, Luxembourg.

$0024-2829 / 93 / 040365+04 \$ 08.00 / 0$

(C) 1993 The British Lichen Society 


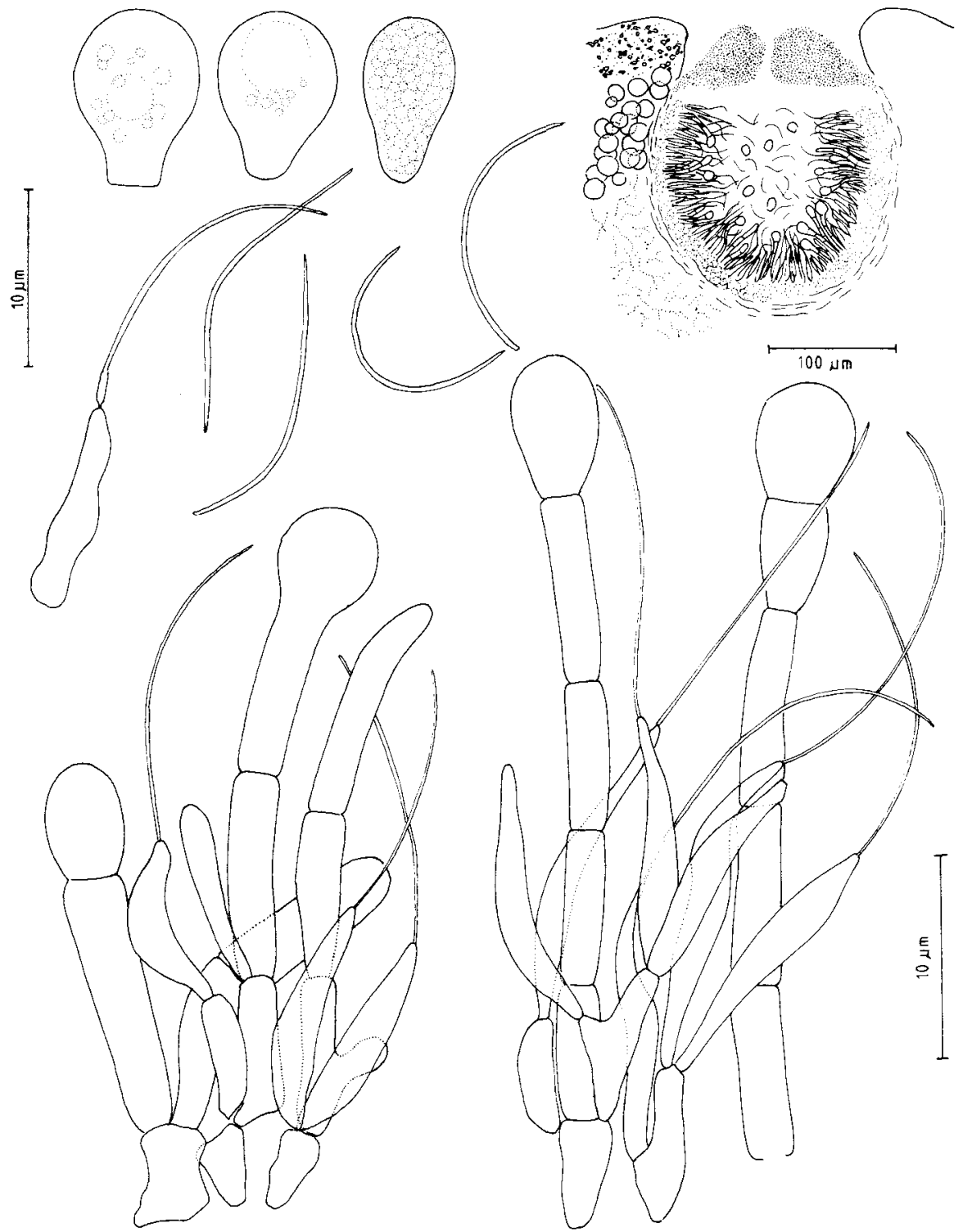

FIG. 1. Conidioma, conidiophores, conidiogenous cells, obpyriform macroconidia and filiform microconidia of Lecanora schistina (Etayo 11395).

diam., 130-210 $\mu \mathrm{m}$ high, ostiolate. Wall hyaline except in the upper part, which is greenish brown, $\mathrm{K}+$ green intensifying, $\mathrm{N}+$ red-brown (Fig. 1).

Microconidial morph predominating and lining the inner surface of the conidiomatal cavity; conidiophores simple with one cell, or septate, arranged more or less parallel, hyaline; conidiogenous cells arising terminally and laterally 

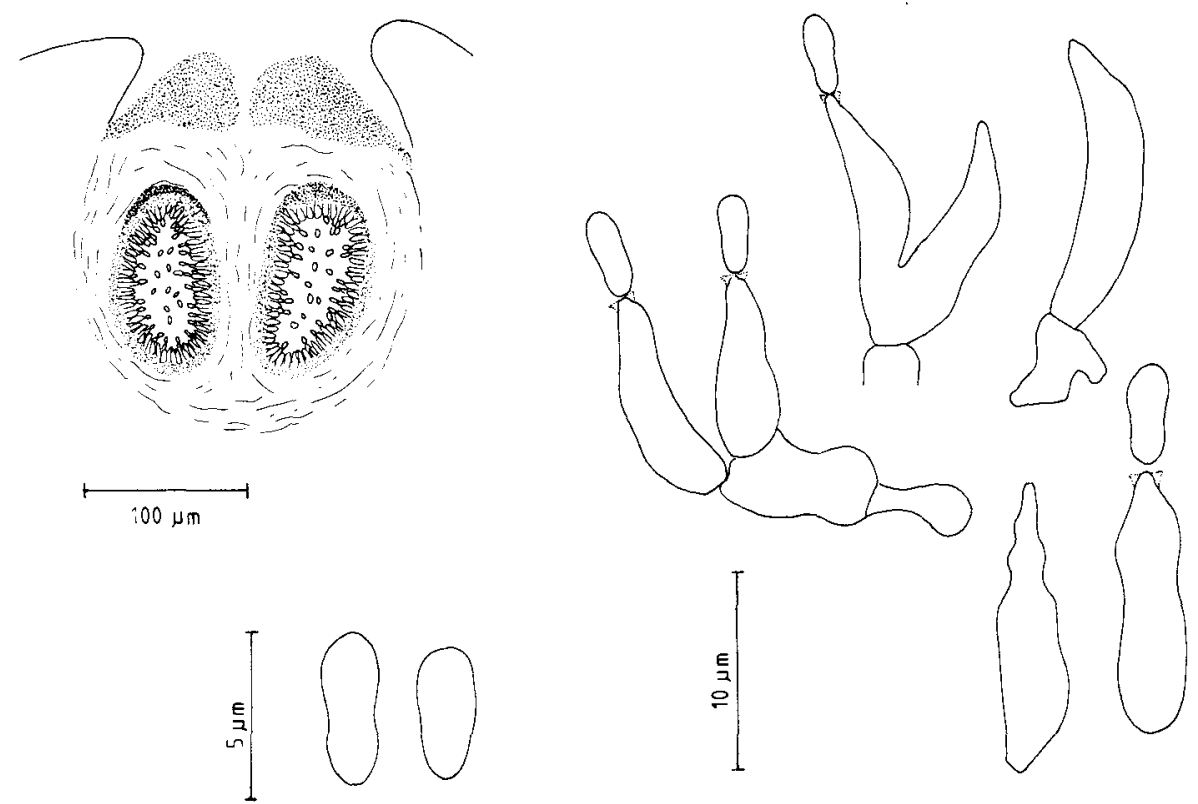

FIG. 2. Conidioma of Lecanora schistina with two locules producing conidiogenous cells and microconidia of the parasitic coelomycete (Etayo 11395).

from the conidiophores, slightly swollen in the central part and tapered towards the apex, hyaline, smooth, 9-14 × 1.5-2 $\mu \mathrm{m}$, producing acrogenous conidia; conidia filiform, often curved, with a pointed apex, simple, hyaline, smooth, $10-23(-28) \times 0.5 \mu \mathrm{m}$.

Macroconidial morph situated between the conidiophores of the microconidial morph, lining the conidiomatal cavity; conidiophores simple or rarely branched in the lower part, hyaline, septate, very variable in size sometimes shorter $(15-20 \mu \mathrm{m})$ or longer $(24-45 \mu \mathrm{m})$, with cells mostly $11-16 \times 2 \cdot 2-3 \mu \mathrm{m}$; conidiogenous cells integrated; conidia acrogenous, hyaline, obpyriform to almost subspherical, clearly truncate at the base, smooth or covered by an irregular gelatinous coat, guttulate, $7-10 \times 5-7 \mu \mathrm{m}$.

Microconidial parasitic conidiomata (Fig. 2) present in a few conidiomata of the host, $80-100 \times 65-75 \mu \mathrm{m}$, bi- or trilocular, wall hyaline except in the light brownish upper part. Conidophores short, hyaline, 5-10 $3-4 \mu \mathrm{m}$. Conidiogenous cells arising terminally and laterally from the conidiophores, tapered towards the apex, hyaline, smooth or sometimes with generally slightly protuberant, unthickened scars, $8-13 \times 2 \cdot 5-3 \cdot 5 \mu \mathrm{m}$. Conidia enteroblastic, hyaline, smooth, ellipsoid to subcylindrical, not guttulate, 4-5 ×1.5-2 $\mu \mathrm{m}$.

Selected specimen examined: Spain: Navarra: Narbarte, valle del Baztán, triassic sandstone, October 1991, F. Etayo 11395 (hb. Etayo).

\section{Discussion}

Macro- and microconidia are both present in the same conidioma. Sometimes the inner conidiomatal cavity is later parasitized by two or three smaller 
conidiomata of a lichenicolous coelomycete in which microconidia are produced. In transverse sections of one conidioma the three kinds of conidia can appear, although the microconidial parasite, when well developed, ends up by destroying the host conidioma.

It is not possible to decide for certain that the ellipsoid microconidia belong to a lichenicolous fungus adapted to living in the conidiomata of Lecanora schistina rather than representing a third morph of the lichen. Further studies of other collections of this species may resolve this problem.

The conidiophores and filiform conidia of the microconidial morph are similar to type III of Vobis (Vobis \& Hawksworth 1981); they are well known and frequent in many other species of Lecanora. Structures similar to the macroconidia are not found in lichens nor in coelomycetes (Sutton 1980).

This is a quite uncommon case within the genus Lecanora as well as within lichenized fungi as a whole. The possibility of the occurrence of conidial dimorphism in other members of Lecanora s. str., to which L. schistina belongs, needs to be investigated before any taxonomic implications can be considered.

The first author is indebted to the DGICYT by a grant ascribed to project number PB89-0518$\mathrm{CO2}-01$.

\section{REFERENCES}

Coppins, B. J. (1983) A taxonomic study of the lichen genus Micarea in Europe. Bulletin of the British Museum (Natural History), Botany series 11: 17-214.

Diederich, P. (1992) Stromatopogon baldwinii Zahlbr., a lichenicolous coelomycete with dimorphic conidia. Lichenologist 24: 371-375.

Sutton, B. C. (1980) The Coelomycetes. Commonwealth Mycological Institute, Kew.

Vobis, G. \& Hawksworth, D. L. (1981) Conidial lichen-forming fungi. In Biology of Conidial Fungi (Cole, G. T. \& Kendrick, B. eds) 1: 245-273. New York: Academic Press. 